\title{
VERTICAL DISTRIBUTION OF MEIOFAUNA IN SEDI- MENTS FROM CONTRASTING SITES IN THE ADRIATIC SEA: CLUES TO THE ROLE OF ABIOTIC VERSUS BIOTIC CONTROL
}

\author{
Leon Moodley ${ }^{1}$, Guotong Chen ${ }^{2}$, Carlo Heip ${ }^{1} \mathcal{F}^{2}$ Magda Vincx ${ }^{2}$ \\ ${ }^{1}$ Netherlands Institute of Ecology, Centre for Estuarine and Coastal Ecology (NIOO-CEMO), P.O. Box 140 \\ 4400 AC, Yerseke, The Netherlands. \\ 'Marine Biology Section, Biology Department, University of Gent, I edeganckstraat 35, B-9000 Gent, Belgium.
}

\begin{abstract}
The rertical profiles of dominant metazoan meiobenthic taxa were studied at four contrasting sites in the Adriatic Sea in relation to macrofaunal activity and oxygen penetration depth in the sediment. Vertical profiles of copepods were related to the oxygen penetration depth and showed peak densities in the upper $\mathrm{cm}$ or deeper in sediments with a broader oxic zone. In contrast, nematodes penetrated much deeper into the sediment and no direct relationship with oxygen penetration depth was evident. Nematode penetration depths were related to or reflected the differences in macrofaunal activity or mixing at the four sites which appears to be an important factor governing the subsurface activity of nematodes.
\end{abstract}

Keywords: Adriatic Sea, meiobenthos, nematodes, vertical distribution, oxygenation, bioturbation.

\section{INTRODUCTION}

Benthic meiofaunal communities are known to be influenced by a complex of interacting factors. The properties of the seabed are most commonly regarded as the principal factors controlling the composition and abundance of the benthos (Gray 1981), but it has also been recognized that food supply may be as important in determining benthic community structure (e.g. Josefson 1987; Grebmeier et al. 1988; Graf 1992; Rosenberg 1995). A positive correlation between abundance or biomass of benthic meiofauna and food availability has been demonstrated (e.g. Elmgren 1978; Thiel 1983; Pfannkuche 1985; Tietjen et al. 1989; Soetaert et al. 1991; Piepenburg et al. 1997; Cook et al. 2000 ), indicating the importance of food avail- ability as a factor controlling meiofaunal populations. However in more productive areas and within a narrow water depth range, this relationship may not be straightforward (e.g. Widbom 1988; Soetaert et al. 1997), and the positive effect of an increased food supply may be counteracted by negative biological interactions with macrofauna, ciliates and protozoans (e.g. Widbom \& Elmgren 1988; Moodley et al. 1998).

Previous studies of the meiobenthos in the Adriatic Sea were restricted to the northern basin (Vidakovic 1988; Tahey et al. 1996; Moodley et al. 1998). In this study, we examine the metazoan meiobenthos in sediments from the northern and middle basins using two proxies for food availability: the chlorophyll $a$ and organic carbon content in the surface sediment.

Meiofauna commonly occur infaunally and, among the dominant metazoan taxa, nematodes are the principal group that penetrate deep into the sediment (e.g. Yingst 1985; Fleeger et al. 1995; Vanreusel et al. 1995). Factors promoting vertical gradients in the sediment are considered to be food availability (e.g. Thiel 1983; Lambshead et al. 1995; Soetaert et al. 1997; Steyaert et al. 1999); oxygenation of the sediment (Shirayama \& Horikoshi 1982), a combination of these factors (Shirayama 1984; Vanreusel et al. 1995), or increased disturbance near the surface (Carman et al. 1987). Macrofaunal activity plays a prominent role in structuring or altering the properties of the sediment column but there are only a few studies of meiobenthos in combination with macrofauna or mixing data (Lambshead et al. 1995). 
Table 1. Bottom water (BW) and sediment parameters $(0-1 \mathrm{~cm})$, oxygen penetration depth and macrofauna data (average $\pm \mathrm{SD}$ ). $\mathrm{nd}=$ not detected.

\begin{tabular}{|c|c|c|c|c|c|c|c|c|c|c|}
\hline \multirow{2}{*}{$\begin{array}{l}\text { Station } \\
\text { Number }\end{array}$} & \multirow{2}{*}{$\begin{array}{c}\text { BW } \\
\text { Temp } \\
\left({ }^{\circ} \mathrm{C}\right)\end{array}$} & \multirow{2}{*}{$\begin{array}{c}\text { BW } \\
\text { Salinity }\end{array}$} & \multirow{2}{*}{$\begin{array}{c}\text { BW } \\
\text { Oxygen } \\
(\mu \mathrm{M})\end{array}$} & \multirow{2}{*}{$\begin{array}{c}\text { Oxygen } \\
\text { Penetration } \\
\text { Depth } \\
(\mathrm{mm})\end{array}$} & \multirow{2}{*}{$\begin{array}{c}\text { Median } \\
\text { Grain } \\
\text { Size } \\
(\mu \mathrm{m})\end{array}$} & \multirow{2}{*}{$\begin{array}{c}\% \text { Silt } \\
(<63 \mu \mathrm{m})\end{array}$} & \multirow{2}{*}{$\begin{array}{l}\mathrm{POC} \\
\left(\mathrm{g} \mathrm{m}^{-2}\right)\end{array}$} & \multirow{2}{*}{$\begin{array}{c}\text { Chlorophyll } a \\
\left(\mathrm{mg} \mathrm{m} \mathrm{m}^{-2}\right)\end{array}$} & \multicolumn{2}{|c|}{ Macrofauna $(0-20 \mathrm{~cm})$} \\
\hline & & & & & & & & & $\begin{array}{c}\text { Abundance } \\
\left(\mathrm{n} \mathrm{m}^{-2}\right)\end{array}$ & $\begin{array}{l}\text { Biomass } \\
\left(\mathrm{gWW} \mathrm{m}^{-2}\right)\end{array}$ \\
\hline 11 & 11.5 & & & & & & 70.4 & $172.2 \pm 4$ & & 498 \\
\hline 2 & 11.0 & 37.4 & 221.8 & $<\overline{2}$ & 10.2 & 99 & $47.8 \pm 2.3$ & $14.1 \pm 2.0$ & $7336 \pm 1517$ & $115 \pm 6.0$ \\
\hline 4 & 11.6 & 38.2 & 244.6 & 11.7 & 8.6 & 100 & $36.1 \pm 1.6$ & $1.7 \pm 0.1$ & $2469 \pm 106$ & $14 \pm 2.5$ \\
\hline 5 & 12.8 & 38.6 & 199.3 & 73.1 & 6.5 & 100 & $9.6 \pm 0.2$ & nd & $564 \pm 0$ & $2 \pm 0.4$ \\
\hline
\end{tabular}

Table 2. Meiobenthos densities (average $\pm \mathrm{SD}$ ) and average contribution of dominant taxa.

\begin{tabular}{ccccccc}
\hline $\begin{array}{c}\text { Station } \\
\text { Number }\end{array}$ & $\begin{array}{c}\text { Total } 0-10 \mathrm{~cm} \\
\left(\mathrm{n} 10 \mathrm{~cm}^{-2}\right)\end{array}$ & $\begin{array}{c}\% \\
\text { Nematoda }\end{array}$ & $\begin{array}{c}\% \\
\text { Copepoda } \\
\text { nauplii }\end{array}$ & $\begin{array}{c}\text { Total } 0-5 \mathrm{~cm} \\
\left(\mathrm{n} 10 \mathrm{~cm}^{-2}\right)\end{array}$ & $\begin{array}{c}\% \\
\text { Nematoda }\end{array}$ & $\begin{array}{c}\% \\
\text { Copepoda } \\
\text { + nauplii }\end{array}$ \\
\hline 11 & $4001 \pm 481$ & 97 & 1 & $3095 \pm 356$ & 96 & 2 \\
2 & $1461 \pm 143$ & 88 & 6 & $1417 \pm 157$ & 88 & 6 \\
4 & $821 \pm 139$ & 66 & 18 & $680 \pm 97$ & 62 & 22 \\
5 & $146 \pm 23$ & 75 & 15 & $138 \pm 24$ & 77 & 14 \\
\hline
\end{tabular}

In this study, we examine vertical distributional patterns of dominant metazoan meiobenthic taxa in relation to the thickness of the oxic layer and sediment mixing (as reflected by chlorophyll $a$ and macrofauna profiles) at four contrasting sites (15 to 1039 meters water depth). Both macrofauna and chlorophyll $a$ profiles provide insight into mixing activity. Because chlorophyll $a$ is highly degradable, deep penetration cannot be a consequence of mere sedimentation so that it reflects mixing or active subduction by organisms. Macrofauna biomass and abundance profiles provide direct information on subsurface activity.

\section{RESULTS}

Fine-grained sediment (muddy silt) was found at all stations (Table 1 ) with very limited varia- tion downcore (data not shown). Bottom water temperature and salinity were comparable between stations (Table 1). The bottom waters were well oxygenated at all four sites but there were large differences in oxygen penetration depth. Penetration was shallowest at the coastal stations $(<2 \mathrm{~mm})$ and deepest at the deep-sea site $(73 \mathrm{~mm}$, Table 1$)$. No free sulphide was detected at any of the stations.

Both proxies for food availability revealed a clear gradient from shallow to deep water with minimum values at the deepest station (station 5, $1039 \mathrm{~m}$ water depth, Table 1).

Nematodes and copepods together made up $84-98 \%$ to the metazoan meiofaunal community (Table 2). Other common, but not abundant, meiobenthic taxa include Polychaeta, Ostracoda, Tanaidacea, Kinorhyncha and Turbellaria. Both total meiofauna and nematode den-

Table 3. List of the 10 dominant nematode genera found in the upper $5 \mathrm{~cm}$ and their relative abundance. ${ }^{*}=$ Family.

\begin{tabular}{cccccccc}
\hline Station 11 & $\%$ & Station 2 & $\%$ & Station 4 & $\%$ & Station 5 & $\%$ \\
\hline Sabatieria & 81.3 & Parodontophora & 12.6 & Dorylaimopsis & 11.2 & Monhysteridae* $^{*} 15.0$ \\
Terschellingia & 8.0 & Halalaimus & 12.1 & Daptonoma & 9.8 & Chromadora & 13.3 \\
Parodontophora & 2.8 & Microlaimus & 11.2 & Monhysteridae* & 9.2 & Halalaimus & 11.7 \\
Daplonema & 2.0 & Sabatieria & 10.5 & Halalaimus & 8.5 & Sabatieria & 11.7 \\
Subsphaerolaimus & 1.9 & Sphaerolaimus & 7.9 & Sphaerolaimus & 7.5 & Hypodontolaimus & 5.0 \\
Aegialoallaimus & 0.6 & Daptonema & 6.9 & Sabatieria & 6.6 & Sphaerolaimus & 5.0 \\
Metalinhomoeus & 0.5 & Terschellingia & 6.8 & Pomponema & 5.9 & Oxystomina & 3.3 \\
Axonolaimus & 0.5 & Dorylaimopsis & 4.6 & Microlaimus & 3.9 & Tricoma & 3.3 \\
Parasphaerolaimus & 0.4 & Campylaimus & 4.5 & Triroma & 3.2 & Scaptrella & 3.3 \\
Metadesmolaimus & 0.4 & Halaphanolaimus & 2.1 & Acantholaimus & 3.0 & Microlaimus & 3.3 \\
\hline
\end{tabular}




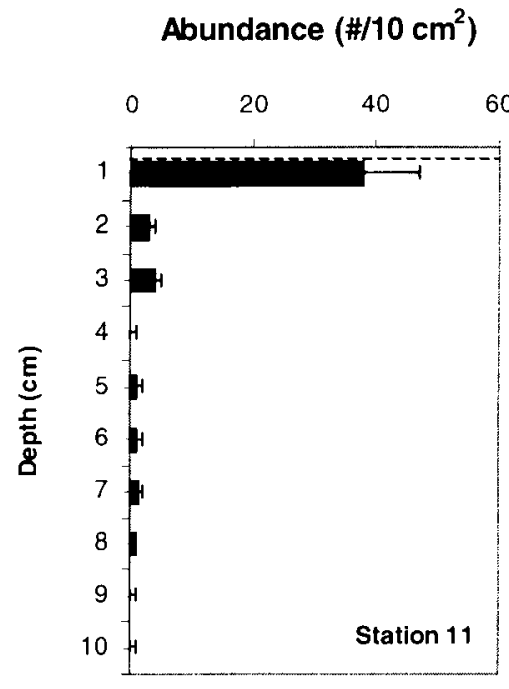

Abundance $\left(\# / 10 \mathrm{~cm}^{2}\right)$

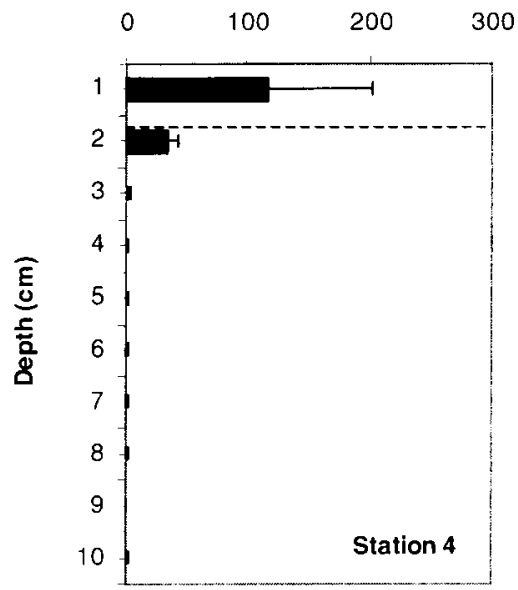

Abundance $\left(\# / 10 \mathrm{~cm}^{2}\right)$

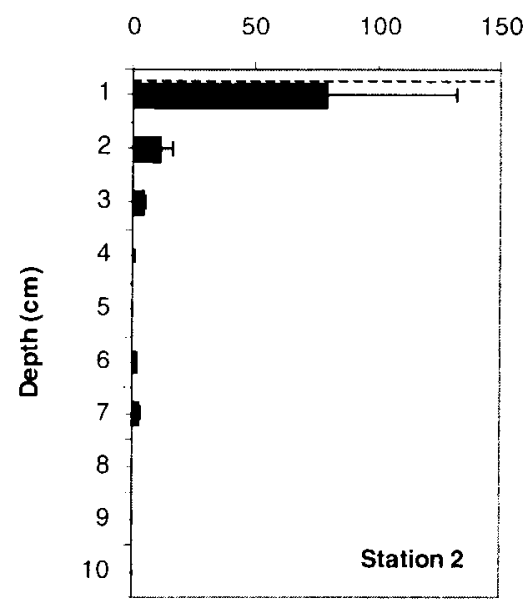

Abundance $\left(\# / 10 \mathrm{~cm}^{2}\right)$

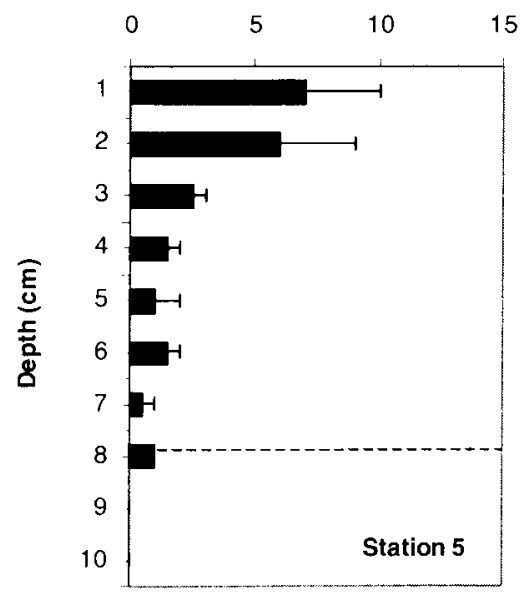

Fig. 1. Vertical profiles of copepods at the four stations (average \pm SD). Dashed lines indicate the oxygen penetration depth.

sities were significantly different between stations (one-way ANOVA, $\mathrm{p}<0.05$ ) but copepod densities were not significantly different between stations. There was a positive correlation between nematode densities and chlorophyll $a$ and POC content $\left(\mathrm{r}^{2}=0.866\right.$ and 0.967 respectively, $\mathrm{p}<0.05$ ). In contrast, copepod densities showed no significant correlation with either chlorophyll $a$ or POC content.

The 10 most dominant nematode genera found in the upper $5 \mathrm{~cm}$ are listed in Table 3 . Generic diversity was the lowest at the richest station (station 11) with a strong dominance of the genus Sabatieria, that constituted $81 \%$ of the assemblage at station 11 but only $7-12 \%$ at the other stations (Table 3).

The vertical distribution of the two dominant meiobenthic taxa (nematodes and copepods) showed two distinct patterns. Peak densities of copepods were found in the surface layers or deeper in the case of a deeper penetration of oxygen (Fig. 1, one-way ANOVA, $\mathrm{p}<$ 0.05 ). However, for nematodes no relationship with oxygen penetration depth was evident. In spite of different oxygen penetration depths, stations 11 and 4 had similar, significantly deeper weighted mean depths than both stations 2 and 5 ( Fig. 2, ANOVA, $\mathrm{p}<0.05$ ). Deepest oxy- 

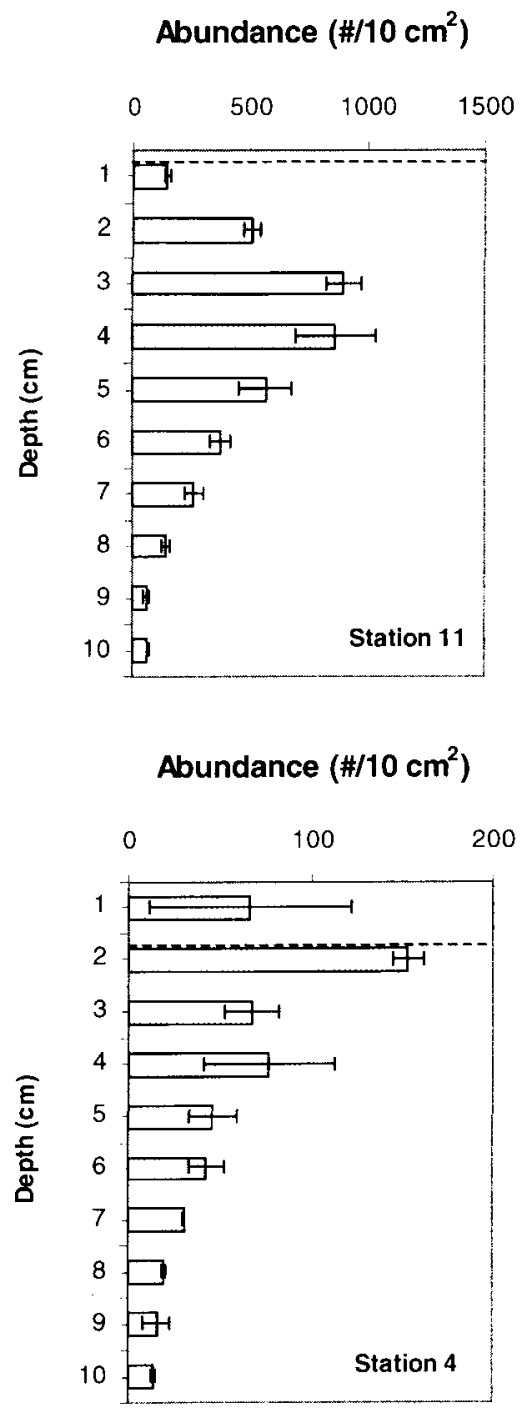

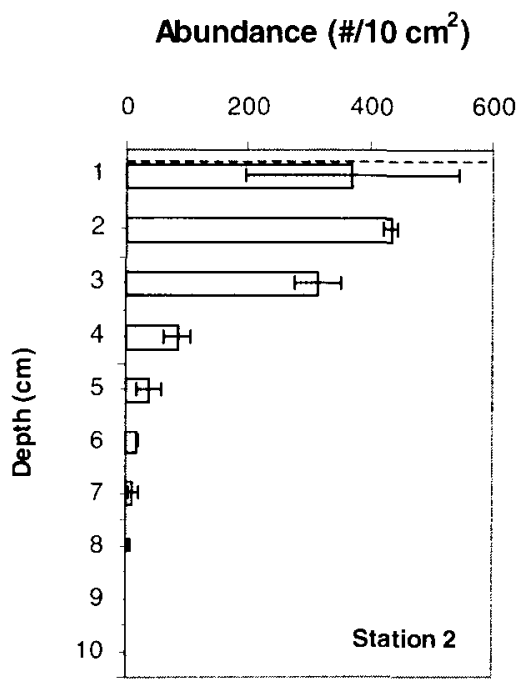

Abundance $\left(\# / 10 \mathrm{~cm}^{2}\right)$

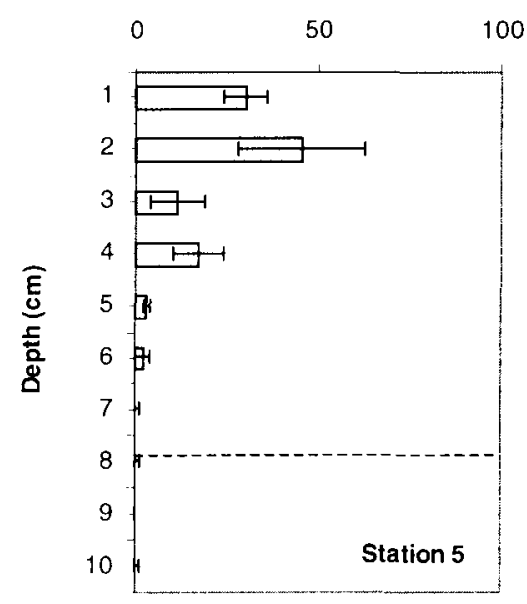

Fig. 2. Vertical profiles of nematodes at the four stations (average \pm SD). Dashed lines indicate the oxygen penetration depth.

gen penetration depth $(73 \mathrm{~mm})$ was found at the deep-sea site (1039 m water depth, station 5 ) and the shallowest at the coastal sites (station $11 \& 2$ ). Station 4 ( $89 \mathrm{~m}$ water depth) had an intermediate oxygen penetration depth of $11 \mathrm{~mm}$.

Station 11 had the largest biomass of macrofauna (Table 1) and although maximum numbers are found within the upper $5 \mathrm{~cm}$, larger specimens inhabited deeper sediment layers (Fig. 3a \& 3b). The striking subsurface biomass peaks at this station were due solely to the polychaete Stermaspis sp. that accounted for $91 \pm 6$ $\%$ of the total biomass over a depth of $20 \mathrm{~cm}$ whilst accounting for only $26 \pm 6 \%$ of the total abundance of macrofauna. At the other shallow station (station 2) only 2 specimens of Sternaspis sp. were found (accounting for $0.04 \%$ of the total biomass) and none at stations 4 and 5 . The abundance and biomass at station 4 was lower but more evenly distributed throughout the sediment column (Fig. 3a \& 3b). In contrast, at stations 2 and 5 macrofauna biomass and abundance showed a sharp decline with depth (Fig. 3a \& 3b) suggesting a relatively lower level of subsurface activity or mixing. The lowest macrofauna biomass was found at the deep-sea site (station 5), where also the lowest 

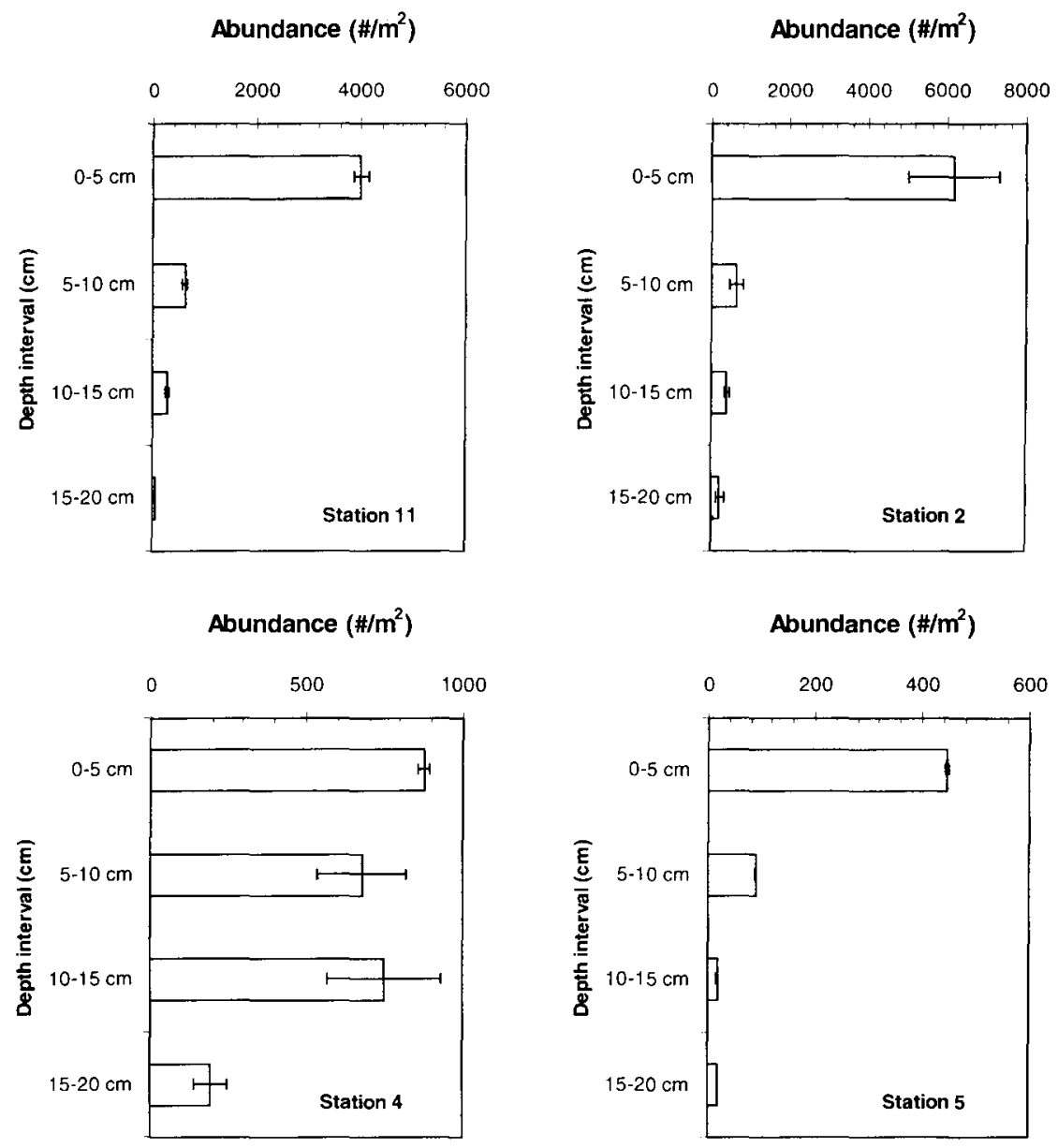

Fig. 3a. Vertical profiles of macrofauna abundance at the four stations (average \pm SD).

average individual biomass was recorded $(3 \mathrm{mg}$ WW compared to 101,16 and $6 \mathrm{mgWW}$ for individuals at stations 11,2 and 4 respectively).

There was a clear difference in chlorophyll $a$ profiles between the two shallow stations, with a deeper penetration at station 11 compared to station 2 (Fig. 4). The relatively shallow penetration at station 4 is probably due to the low concentration of chlorophyll $a$ in the surface sediment rather than limited subsurface activity as suggested by macrofauna profiles (Fig. 3a \& 3b). No chlorophyll $a$ was detected in sediments of station 5 .

\section{DISCUSSION}

Although this study is limited to four sites, several trends are evident and in accordance with recent observations. The oxygen penetration depth in sediments is strongly related to the organic matter content, with limited penetration in organically rich coastal sediments such as the northwestern Adriatic Sea (Epping \& Helder 1998; Moodley et al. 1998) and deeper penetration in deeper waters characterized by low organic matter input (e.g. Helder \& Epping 1995; Soetaert et al. 1996). The absence of free sulphide in organic rich sediments of the northwestern Adriatic Sea has been related to the high reactive $\mathrm{Fe}$ content of the sediment (Barbanti et al. 1995; Moodley et al. 1998).

In accordance with earlier studies in the Adriatic Sea, nematodes and copepods were the dominant components of the metazoan meiobenthos (Vidakovic 1988; Tahey et al. 1996; Moodley et al. 1998). However, copepods did not occur in large numbers and their densities were not significantly different between 

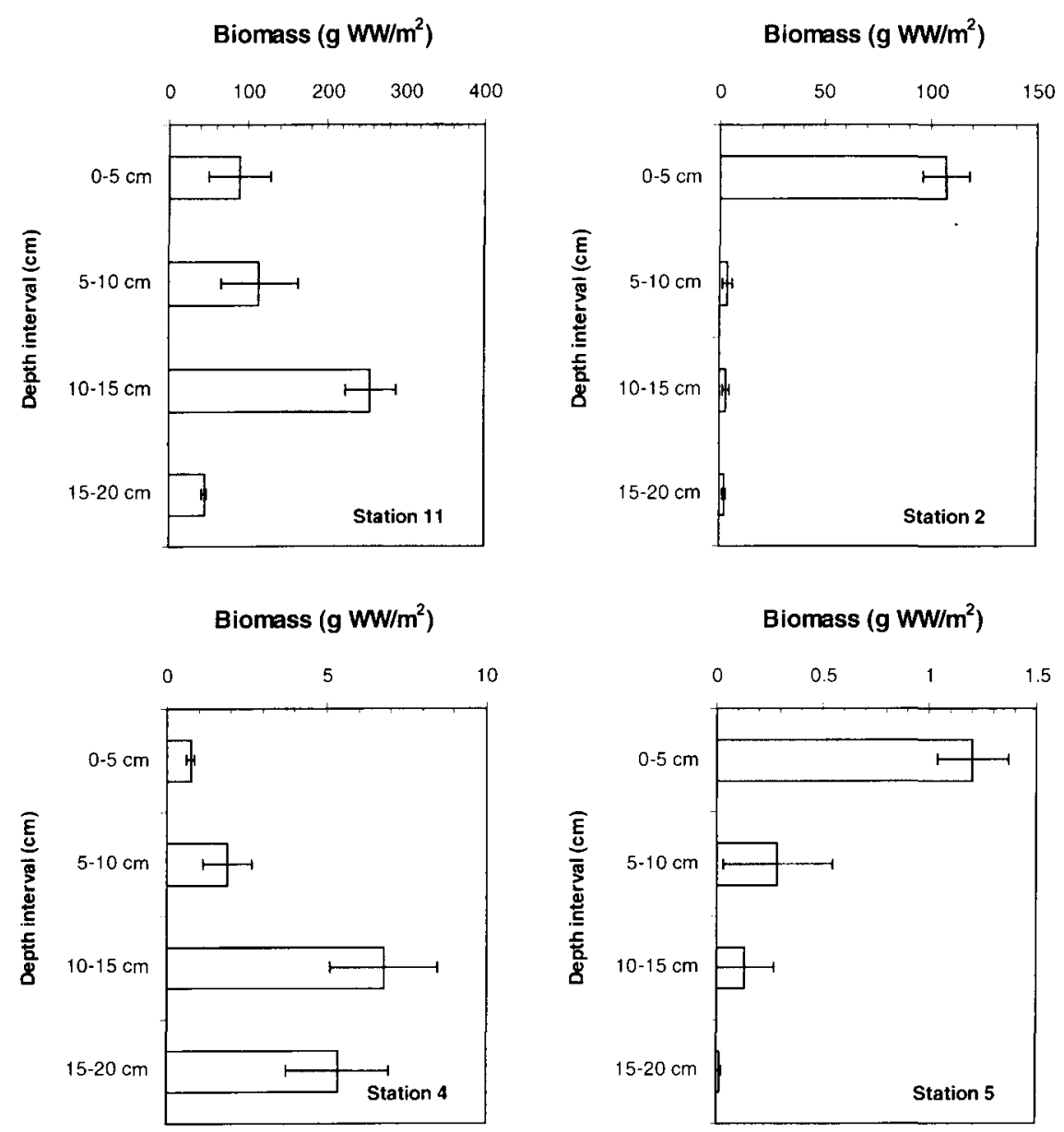

Fig. 3b. Vertical profiles of macrofauna biomass at the four stations (average \pm SD).

stations. Nematodes are generally the dominant component in fine-grained sediments and a positive correlation was found between food availability and nematode standing stock over 5 or $10 \mathrm{~cm}$ sediment depth. This confirms the role of food availability as a factor controlling nematode densities, at least over the broad range of food content examined in this study. However, station 11 which supported the highest densities also had the lowest generic diversity with a strong dominance of Sabatieria (81 $\%$, Table 3). High dominance of this genus is often associated with oxygen depleted sediments (e.g. Jensen 1983; Vincx 1990; Olafsson 1992; Hendelberg \& Jensen 1993) but station 2 with a similar oxygen penetration depth had a lower dominance of Sabatieria (11\%) and Sabatieria constituted $12 \%$ of the nematode assemblage at station 5 (Table 3 ). This together with the high dominance of one polychaete (Sternaspis) at station 11 suggests that other, site-specific factors may be more important rather than oxygenation directly. However, trends may be different at the species level as Sabatieria spp. exhibits a wide range of ecological preferences (Steyaert et al. 1999).

Although vertical profiles of copepods seem to fit patterns of oxygen penetration depth, this clearly does not apply to nematodes. In spite of the deep penetration of oxygen at the deep-sea station ( $73 \mathrm{~mm}$, station 5 ), nematodes were concentrated in the upper layers as was the case at station 2 with a much lower oxygen penetration depth (less than $2 \mathrm{~mm}$ ). A significantly deeper penetration was found at the other two stations (station 11 \& 4) characterized by relatively higher levels of mixing activity (as indicated by macrofauna and chlorophyll $a$ pro- 

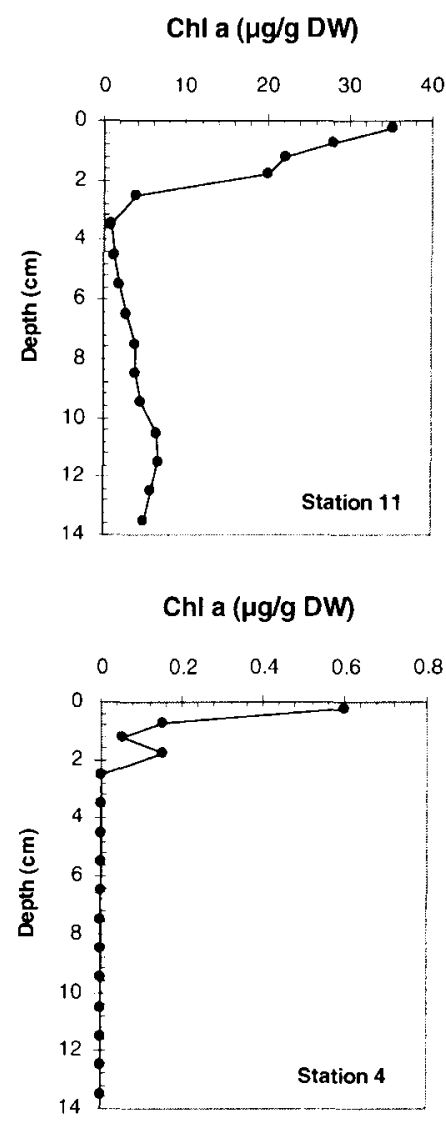

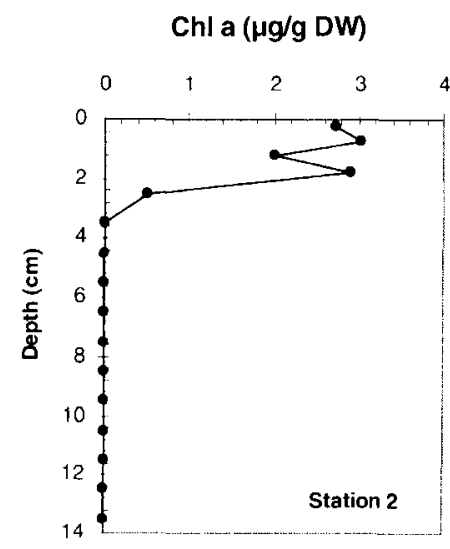

Fig. 4. Chlorophyll $a$ profiles in sediments of the different stations. No chlorophyll a was detected at station 5. files, Figs. $3 \& 4$ ) but shallow oxygen penetration. This clearly demonstrates that the depth of the oxic zone does not necessarily delineate the habitat depth of nematodes and that nematode penetration into the sediment is closely related to mixing activities.

The ability of organisms to alter the properties of the sediment is mainly a function of their activity and size (Wheatcroft et al. 1990) and deep mixing of sediments is mainly due to macrofaunal activity (Aller 1984; Smith 1992; Soetaert et al. 1997; Boudreau 1998). Because of their relatively small size (on average, less than $1 \mathrm{~mm}$ long) one can assume the nematodes have only limited impact on the geochemistry of their environment (Soetaert et al. 1997). Consequently, vertical distribution of nematodes will be established as a response to the geochemical properties created by larger organisms (Soetaert et al. 1997), assuming that passive transport of nematodes does not play an important role. Two sediment features that can affect the distribution of higher organisms are food abundance and oxygen availability; the concentration or presence of which in deeper sediment layers is strongly governed by mixing activities. In organic rich sediments with limited oxygen penetration (as registered by microelectrodes or chemical compounds), a substantial part of nematode assemblages are found below the oxic zone (e.g. Hengelberg \& Jensen 1991; Soetaert et al. 1997; Steyaert et al. 1999, this study). However, infaunal habitats are, as a result of macrofaunal activity, not permanently anoxic; macrofauna activity evidently provides intermittent traces of oxygen (e.g. Boudreau \& Marinelli 1994). With limited exceptions (Vopel et al. 1996), copepods are generally more sensitive to severe oxygen depletion or anoxia than nematodes (Elmgren 1975; Murrell \& Fleeger 1989; Moodley et al. 1997; Modig \& Olafsson 1998) which may explain the vertical profiles of copepods. In accordance with earlier observations, oxygenation seems to have a limited direct impact on nematode vertical distribution (Soetaert et al. 1997). Our ob- 


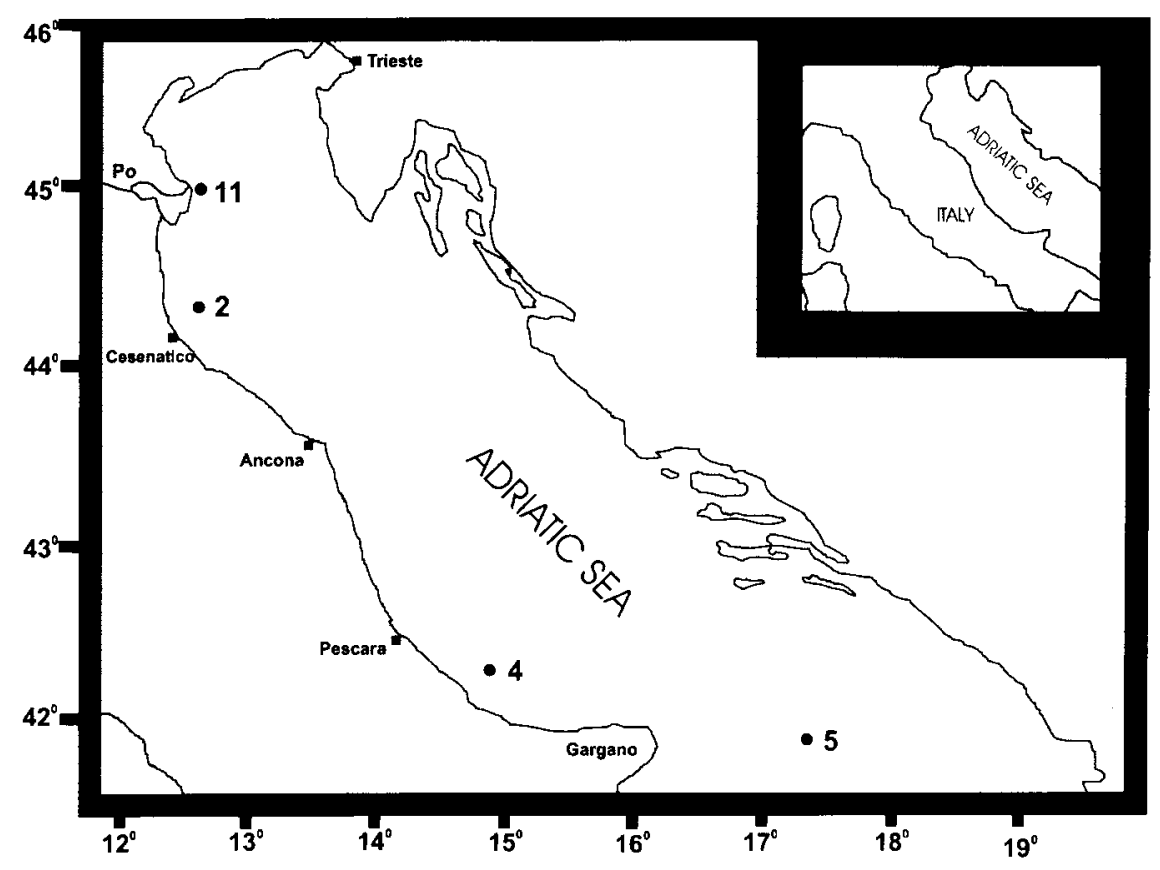

Fig. 5. Location of sampling stations.

servations suggest that, provided that sediments are not sulphidic or continuously anoxic, oxygen may not the prime factor governing nematode distribution as it seems to affect $\mathrm{CO}^{-}$ pepods.

In a study along a depth gradient in the northeastern Atlantic, Soetaert et al. (1997) found a positive relationship between nematode vertical distribution and the vertical distribution of nitrogen (indicator of food content) in the sediment that was related to differential sediment mixing. Peak densities of nematodes were found in surface sediments at sites having limited mixing activity. Similarly, in our study, vertical profiles of nematodes were related to macrobenthic activity. However, our nematode profiles do not match chlorophyll $a$ profiles; maximum values of chlorophyll $a$ were found in the surface layers whereas nematodes had subsurface peaks. However, it should be noted that chlorophyll $a$ represents only one pool of labile organic matter. Irrespective, nematodes evidently exploit subsurface conditions created by macrofauna activity.

\section{MATERIALS AND METHODS}

The metazoan meiobenthos (permanent + temporary) were studied at four sites in the
Adriatic Sea in April/May 1995 (Table 4). Station 11 was located close to the delta of the river Po, stations 2 and 4 were in the western and middle continental shelf and station 5 in the central basin at the base of the continental slope (Fig. 5). Sediment parameters were measured in sediment cores (perspex cores with 3.6 $\mathrm{cm}$ i.d.) that were taken from undisturbed boxcore samples. Cores were sliced on board within 2 hours. Grain size analysis were done with a Malvern Particle Analyser. Porosity was calculated from the water content of the sediment, assuming a density of 2.55 for sediment and $1.003 \mathrm{~g} \mathrm{~cm}^{-3}$ for seawater density. The organic carbon content was analysed with a Carlo Erba NA 1500 CN Analyser according to Nieuwenhuize et al. (1994). The chlorophyll $a$ content was analysed by means of reverse-phase HPLC and the lower limit of detection was $0.015 \mu \mathrm{g}$

Table 4. List of stations, position and water depth.

\begin{tabular}{cccc}
\hline $\begin{array}{c}\text { Station } \\
\text { Number }\end{array}$ & \multicolumn{2}{c}{ Position } & $\begin{array}{c}\text { Water } \\
\text { Depth }(\mathrm{m})\end{array}$ \\
\hline 11 & $44^{\circ} 58^{\prime} 04^{\prime \prime} \mathrm{N}$ & $12^{\circ} 34^{\prime} 51^{\prime \prime} \mathrm{E}$ & 15 \\
2 & $44^{\circ} 18^{\prime} 24^{\prime \prime} \mathrm{N}$ & $12^{\circ} 34^{\prime} 39^{\prime \prime} \mathrm{E}$ & 19 \\
4 & $42^{\circ} 16^{\prime} 40^{\prime \prime} \mathrm{N}$ & $14^{\circ} 54^{\prime} 18^{\prime \prime} \mathrm{E}$ & 89 \\
5 & $41^{\circ} 53^{\prime} 00^{\prime \prime} \mathrm{N}$ & $17^{\circ} 24^{\prime} 24^{\prime \prime} \mathrm{E}$ & 1039 \\
\hline
\end{tabular}


chlorophyll $a$ per $\mathrm{g}$ dry sediment. Values of both \% POC and chlorophyll $a$ were converted to content per area using the porosity and assuming a dry density of $2.55 \mathrm{~g} \mathrm{~cm}^{-3}$ for sediment.

The oxygen penetration depth was determined with glass microelectrodes with a built in reference electrode connected to a Keithley picoammeter. Profiling was done immediately using a micro-manipulator at in situ temperature. The lowest consistently repeated value at depth in a subcore was taken as zero oxygen. Sediment was also profiled for sulfide, using a metal microelectrode and a calomel reference electrode, connected to a Radiometer $\mathrm{pH} / \mathrm{mil}$ livolt meter.

For macrofauna, boxcores were subsampled with perspex cores (i.d. $19 \mathrm{~cm}$ ). Duplicate sediment samples were sliced in $5 \mathrm{~cm}$ slices down to $20 \mathrm{~cm}$ and then washed over a $0.5 \mathrm{~mm}$ sieve. The fraction $>0.5 \mathrm{~mm}$ was preserved in borax buffered $4 \%$ formalin with rose Bengal. In the laboratory, organisms were sorted and counted under a stereo microscope and categorized in taxonomic groups. Biomass determinations were made by weighing formalin preserved samples (excluding shells of molluscs and tubes of polychaetes and amphipods), after blotting on absorbent paper.

For the meiofauna, duplicate samples (perspex cores with i.d. of $3.6 \mathrm{~cm}$ ) were taken from boxcores. The sediment was sliced in $1 \mathrm{~cm}$ slices and stored in borax buffered $4 \%$ formalin with rose Bengal. In the laboratory, the fraction $>38 \mu \mathrm{m}$ was analysed. Meiofauna was first separated from the sediment by centrifuging with Ludox HS 40. Stained specimens of both permanent and temporary meiofauna were identified to major taxon level and counted. The nematodes in the different layers within the upper $5 \mathrm{~cm}$ of single cores were identified to genus level. Fifty nematodes per sediment interval (or all specimens in samples that had low numbers) were picked at random and mounted in glycerine slides.

All data were $\ln$ transformed before statistical analysis by one-way analysis of variance (ANO$\mathrm{VA)}$ or by linear regression analysis using the MGLH module of SYSTAT (Systat Inc.). In order to compare the vertical distribution, the weighted mean depth was calculated using non-transformed data (Fleeger et al. 1995).

We thank Karline Soetaert and Jack J. Middelburg for important comments on the manuscript. G. Chen is sincerely grateful to Prof. Dr. A Coomans for his kind en- couragement and the Marine Biology Section, University of Gent for the facilities available and financial support. Special thanks to Jan Belgers and Eric Slim for field assistance. We are grateful to the Captain and crew of the R.V. Urania for their assistance in the collection of the samples. This work has been undertaken in the framework of the Mediterranean Targeted project (MTP)-Euromarge-AS project. We acknowledge the support from the European Commission's Marine Science and Technology (MAST) Programme and the Netherlands Organization for Scientific Research, Earth-and Life Sciences. This is publication 2709 of the NIOO-CEMO.

\section{REFERENCES}

Aller, R.C. 1994. The importance of relict burrow structures and burrow irrigation in controlling sedimentary solute distribution. - Geochimica et Cosmochemica Acta 48: 1929-1934.

Barbanti, A., M.C. Bergamini, F. Frascari, S. Miserocchi, M. Ratta, \& G. Rosso 1995. Diagenetic processes and nutrient fluxes at the sediment-water interface, northern Adriatic Sea, Italy. - Mar. Freshwater Res. 46: 55-67.

Boudreau, B.P. 1998. Mean mixed depth of sediments: The wherefore and the why, - Limnol. Oceanogr. 43: 524-526.

Boudreau, B.P. \& R.L. Marinelli 1994. A modelling study of discontinuous biological Irrigation. - J. Mar. Res. 52: 947-968.

Carman, K.R., K.M. Sherman \& D. Thistle 1987. Evidence that sediment type influences the horizontal and vertical distribution of nematodes at a deep-sea site. - Deep-sea Res. 34: 45-53.

Cook, A.A., P.J.D. Lambshead, L.E. Hawkins, N. Mitchell \& L. Levin 2000. Nematode abundance at the oxygen minimum zone in the Arabian Sea.- Deep-Sea Res. II 47: $75-85$.

Elmgren, R. 1975. Benthic meiofauna as indicator of oxygen conditions in the northern Baltic proper. Merentutkimuslait. Julk. 239: 265-271.

Elmgren, R. 1978. Structure and dynamics of Baltic benthos communities, with particular reference to the relationship between macro-and meiofauna. - Kieler Meeresforsch. Sonderh. 4: 1-22.

Epping, E.H.G. \& W. Helder 1998. Oxygen budgets for northern Adriatic sediments calculated from in situ oxygen profiles. - Cont. Shelf Res. 17: 1737-1764.

Fleeger, J.W., T.C. Shirley, J.N. McCall 1995. Fine-scale vertical profiles of meiofauna in muddy subtidal sediments. - Can. J. Zool. 73: 1453-1460.

Graf, G. 1992. Benthic-pelagic coupling: a benthic view. - Oceanogr. Mar. Biol. Ann. Rov. 30: 149-190.

Gray, J.S. 1981. The Ecology of marine sediments. Cambridge University Press, New York, $185 \mathrm{pp}$.

Grebmeier, J.M., C.P. McRoy \& H.M. Feder 1988. Pelagic-benthic coupling on the shelf of the northern Bering and Chikchi Sea. I. Food supply and benthic biomass. - Mar. Ecol. Prog. Ser. 48: 57-67.

Helder, W. \& E. Epping 1995. Mineralization of organic matter along a transect in the Goban Spur area (Celtic Sea). - In Ocean Margin Exchange, second annual report, Pp E93-E104. ULB, Brussels.

Hendelberg, M. \& P. Jensen 1993. Vertical distribution of the nematode fauna in a coastal sediment influenced by seasonal hypoxia in the bottom water. - Ophe- 
lia 37: 83-94.

Jensen, P. 1983. Meiofaunal abundance and vertical zonation in a sublittoral soft bottom, with a test of the Haps corer- Mar. Biol. 74: 319-327.

Josefson, A.B. 1987. Large-scale patterns of dynamics in subtidal macrozoobenthic assemblages in the Skagerrak: effects of a production-related factor? - Mar. Ecol. Progr: Ser. 38: 13-23.

Lambshead, P.J., T.J. Ferrero \& G.A. Wolli 1995. Comparison of the vertical distribution of nematodes from two contrasting abyssal sites in the northeast Atlantic subject to different seasonal inputs of phytodetritus. Int. Revue ges. Hydrobiol. 80: 327-331.

Modig, H. \& E. Olafsson 1998. Responses of Baltic benthic invertebrates to hypoxic events. - J. Exp. Mar: Biol. Ecol. 229: 133-148.

Moodley; L., G.J. van der Zwaan, P.M.J. Herman, L. Kempers \& P. van Breugel, P 1997. Differential response to benthic meiofauna to anoxia with special reference to foraminifera (Protista: Sarcodina). - Mar. Ecol. Prog. Ser. 158: 151-163.

Moodley, L., C.H.R. Heip \& J.J. Middelburg 1998. Benthic activity in sediments of the northwestern Adriatic Sea: sediment oxygen consumption, macro-and meiofauna dynamics. - J. Sea Res. 40: 263-280.

Murrell, M.C. \& J.W. Fleeger 1989. Meiofauna abundance on the Gulf of Mexico continental shelf affected by hypoxia. - Cont. Shelf Res. 9: 1049-1062.

Nieuwenhuize, J.Y.E.M. Maas \& J.J. Middelburg 1994. Rapid analysis of organic carbon and nitrogen in particulate materials. - Mar. Chem. 45: 217-224.

Olafsson, E. 1992. Small-scale distribution of marine meiobenthos: the effects of decaying macrofauna. Oecologia 90: 37-42.

Pfannkuche, O. 1985. The deep-sea meiofaund of the Porcupine Seabight and abyssal plain (NE Atlantic): population structure, distribution, standing stocks. Oceanol. Acta 8: 343-353.

Piepenburg, D., W.G. Ambrose, A. Brandt, P.E. Renaud, M.J. Ahrens \& P. Jensen 1997. Benthic community patterns reflect water column processes in the Northeast Water polynya (Greenland), - J. Mar. Systems 10: 467-482.

Rosenberg, R. 1995. Benthic marine fauna structured by hydrodynamic processes and food availability. - Neth.J. Sea Res. 34: 303-317.

Shiravama, Y. 1984. The abundance of deep sea meiobenthos in the western Pacific in relation to environmental factors. - Oceanol. Acta 7: 113-121.

Shirayama, Y. \& M. Horikoshi 1982. Vertical distribution of smaller macrobenthos and larger meiobenthos in the sediment profile in the deep-sea system of Suruga Bay (central Japan). - J. Oceanogr. Soc. Jap. 38: 276-280.

Smith, C.R. 1992. Factors controlling bioturbation in deep-sea sediments and their relation to models of carbon diagenesis. - In G.T. Rowe, \& V. Pariente (eds): Deep-Sea Food Chains and Global Carbon, pp 375-393. Kluwer Academic, Dordrecht.

Soetaert, K., C. Heip \& M. Vincx 1991. The meioben- thos along a Mediterranean Deep-Sea transect off Calvi (Corsica) and in an adjacent canyon. - P.S.Z.N.I. Marine Ecology 12: 227-242.

Soetaert, K., P.M.J. Herman \& J.J. Middelburg 1996. A model of early diagenetic processes from the shelf to abyssal depths. - Geochimica et Cosmochemica Acta 60: 1019-1040.

Soetaert, K., J. Vanaverbeke, C. Heip, P.M.J. Herman, J.J. Middelburg, A. Sandee \& G. Duineveld 1997. Nematode distribution in ocean margin sediments of the Goban Spur (North-East Atlantic) in relation to sediment geochemistry. - Deep-Sea Res. 44: 1671-1683.

Steyaert, M., N. Garner, D. van Gansbeke \& M. Vincx 1999. Nematode communities from the North Sea: environmental controls on species diversity and vertical distribution within the sediment. - J. Mar. Biol. Ass. U.K. 79: 253-264.

Tahey, T.M., G.C.A. Duineveld, P.A.W.J. De Wilde, E.M. Berghuis \& A. Kok 1996. Sediment $\mathrm{O}_{2}$ demand, density and biomass of the benthos and phytopigments along the northwestern Adriatic coast: the extent of Po enrichment. - Oceanologica Acta 19: 117-130.

Thiel, H. 1983. Meiobenthos and nannobenthos of the deep-sea. - In C. Rowe (ed.): The Sea, Vol. 8. Depp-Sea Biology, pp. 167-230. Wiley, New York.

Tietjen, J.H., J.W. Deming, G.T. Rowe, S. Macko \& R.J. Wilke 1989. Meiobenthos of the Hatteras Abyssal Plain and Puerto Rico Trench: abundance, biomass and associations with bacteria and particulate fluxes. Deep-Sea Res. 36: 1579-1594.

Vanreusel, A., M. Vincx, D. Schram \& D. van Gansbeke 1995. On the vertical distribution of the metazoan meiofauna in shelf break and upper slope habitats of the NE Atlantic. - Int. Rorue ges. Hydrobiol. 80: 313-326.

Vidakovic, J. 1988. Meio-and nematofauna from Rasa Bay (north Adriatic Sea,Yugoslavia), - Vie Milien 38: 213-220.

Vincx, M. 1990. Diversity of nematode communities in the southern Bight of the North Sea. - Neth.J. Sea Res. 25: $181-188$.

Vopel, K., J. Dehmlow \& G. Arlt 1996. Vertical distribution of Cletocamptus confluens (Copepoda, Harpacticoida) in relation to oxygen and sulphide microprofiles of a brackish sulphuretum. - Mar. Ecol. Prog. Ser: 141: 129-137.

Wheatcroft, R.A., P.A. Jumars, C.R. Smith \& A.R.M. Nowell 1990. A mechanistic view of the particulate biodiffusion coefficient: step lengths, rest periods and transport directions. - J. Mar. Res. 48: 177-207.

Widbom, B. 1988. The Benthic Meiofauna of Three Coastal Areas: Structure, Seasonal Dynamics and Response to Environmental Pertubations. Doctoral thesis, University of Stockholm, 164 pp.

Widbom, B. \& R. Elmgren 1988. Response of benthic meiofauna to nutrient enrichment of experimental marine ecosystems. - Mar. Ecol. Prog. Ser. 42: 257-268.

Yingst, J.Y. 1978. Patterns of micro-and meiofaunal abundance in marine sediments, measured with the adenosine triphosphate assay. - Mar. Biol. 47: 41-54. 